\title{
PERAN PENYULUH PERTANIAN TERHADAP HASIL PRODUKSI PADI SAWAH DI DESA CIBUNIASIH KECAMATAN PANCATENGAH KABUPATEN TASIKMALAYA
}

\author{
AGRICULTURAL EXTENSION RULE DEAL WITH WETLAND PADDY \\ PRODUCTION AT CIBUNIASIH, PANCATENGAH, DISTRICT TASIKMALAYA
}

\author{
Soni Ariana, Ristina Siti Sundari*, Dona Setia Umbara \\ Universitas Perjuangan, Jl. PETA No. 177 Tasikmalaya 46115 \\ *E-mail: ristina.sitisundari@yahoo.com \\ (Diterima 09-06-2021; Disetujui 05-07-2021)
}

\begin{abstract}
ABSTRAK
Penyuluhan merupakan suatu proses pembelajaran secara non formal untuk memberikan ilmu pengetahuan, pelatihan, teknologi, permodalan, dan merubah perilaku petani menjadi lebih mandiri dalam mengambil keputusan. Peran penyuluh dalam kegiatan penyuluhan yaitu sebagai pembimbing, organisator, teknisi dan konsultan untuk membantu petani mengembangkan usahatani dan meningkatkan produksi. Penelitian ini bertujuan untuk mengetahui pengaruh peran penyuluh pertanian terhadap hasil produksi padi sawah di Desa Cibuniasih. Metode penelitian yang digunakan adalah survei dan wawancara terhadap 68 responden yaitu petani padi sawah di Desa Buniasih, kemudian dianalisis menggunakan uji regresi linier berganda. Hasil penelitian menunjukkan bahwa peran penyuluh pertanian berpengaruh signifikan sebesar $66,6 \%$ terhadap hasil produksi padi di Desa Cibuniasih. Peran penyuluh pertanian sebagai pembimbing dan konsultan memberikan pengaruh yang signifikan terhadap hasil produksi padi sawah, artinya kinerja penyuluh dalam kegiatan pembimbingan dan konsultansi dengan petani berjalan baik. Tetapi peran penyuluh pertanian sebagai organisator dan teknisi belum berpengaruh signifikan terhadap produksi padi, karena pengenalan teknologi yang masih belum sesuai dan kebutuhan petani belum terpenuhi dengan baik.
\end{abstract}

Kata kunci: Penyuluh Pertanian, Produksi, Padi Sawah

\section{ABSTRACT}

Extension is a non-formal learning process to provide knowledge, training, technology, capital, and change the behavior of farmers to be more independent in making decisions. The role of the extension agent in extension activities is as a guide, organizer, technician and consultant to help farmers develop farming and increase production. This study aims to determine the effect of the role of agricultural extension workers on the production of lowland rice in Cibuniasih Village. The research method used is a survey and interviews with 68 respondents, namely rice farmers in Buniasih Village, then analyzed using multiple linear regression. The results showed that the role of agricultural instructors had a significant effect of $66.6 \%$ on rice production in Cibuniasih Village. The role of agricultural instructors as supervisors and consultants has a significant influence on the results of lowland rice production, meaning that the performance of extension workers in mentoring and consulting activities with farmers is going well. However, the role of agricultural extension workers as organizers and technicians has not had a significant effect on rice production, because the introduction of technology is still not appropriate and the needs of farmers have not been met properly.

Keywords: Agricultural extention; production; wetland paddy 


\section{PENDAHULUAN}

Salah satu wilayah di Provinsi Jawa Barat dengan jumlah produksi padi sawah yang cukup tinggi yaitu Kabupaten Tasikmalaya. Jumlah produksi padi sawah di Kabupaten Tasikmalaya dari tahun 2015-2019 mengalami kenaikan meski tidak terlalu besar, meski luas panen padi mengalami penurunan pada tahun 2019 sebanyak 139 hektar. Wilayah Kabupaten Tasikmalaya terdiri atas 39 kecamatan yang sebagian besar komoditi unggulannya adalah padi sawah, salah satunya adalah Kecamatan Pancatengah (Hikmahwidi, 2018). Kecamatan Pancatengah dari tahun 20152019 memiliki luas panen padi sawah yang fluktuatif dengan hasil produksi padi sawah yang cenderung mengalami penurunan. Pada tahun 2019 mengalami penurunan yang drastis dengan jumlah produksi padi hanya sebesar 28.122 ton (BPS Kabupaten Tasikmalaya, 2019).

Turunnya produksi padi dipengaruhi oleh beberapa faktor seperti kesuburan tanah, pemakaian pupuk, bibit, cara bercocok tanam, hama, curah hujan, tenaga kerja, luas lahan, jarak lahan dengan rumah dan sistem irigasi (Ishaq et al., 2017). Tingkat produktivitas tergantung dari kinerja pelaku utama sebagai pengelola untuk menerapkan dan mengadopsi teknologi, pengetahuan, kemampuan, serta didukung dengan aspek sosial ekonomi untuk membantu meningkatkan produktivitas (Sundari et al., 2015).

Taraf keberhasilan pertanian di masa yang akan datang merupakan hasil dari peningkatan kualitas petani dan analisis permasalahan pertanian yang terjadi saat ini. Model perencanaan yang digunakan harus menjadi terobosan pemecahan masalah sebagai upaya untuk meningkatkan kualitas pertanian di masa yang akan datang (Umbara et al., 2019) dan ketahanan pangan serta mendukung SDGs poin 1, 2 dan 3 (Sundari et al., 2021). Penyuluh dapat mempengaruhi objek penyuluhan melalui perananya dengan aspek sebagai pembimbing, organisator, teknisi dan konsultan. Melalui pengembangan kelompok tani yang sesuai dengan karakteristik petani termasuk sumber daya yang dimiliki yang dilaksanakan untuk meningkatkan kualitas pertanian yang dikelola oleh petani (Putra et al., 2018).

Kinerja penyuluhan untuk pengembangan pertanian merupakan kegiatan nyata dari tugas penyuluh yang diukur dengan tingkat kepuasan petani. Tugas pokok penyuluh untuk mengembangkan kapasitas dan 
kemandirian petani terdiri atas pengembangan perilaku inovatif, penguatan partisipasi, kelembagaan tani, akses sumberdaya, kemampuan petani berjaringan, dan kaderisasi (Sutrisno, 2016).

Penduduk pedesaan hampir secara keseluruhan bergantung pada sektor pertanian. Potensi yang dimiliki perlu didukung dengan tenaga kerja penyuluh pertanian yang berkompeten, untuk mendorong sektor pertanian agar mampu merubah petani menjadi lebih sejahtera (Vintaro et al., 2019).

Potensi desa yang perlu dikembangkan salah satunya adalah Desa Cibuniasih yang terletak di Kecamatan Pancatengah Kabupaten Tasikmalaya. Daerah dataran rendah yang subur, berada pada ketinggian berkisar antara 100-150 meter dpl dengan luas wilayah 1.900 Ha. Potensi yang dimiliki Desa Cibuniasih yaitu dari aspek pertanian terutama tanaman pangan karena sebagian besar masyarakatnya bermata pencaharian sebagai petani. Tanaman pangan merupakan penyumbang pendapatan desa kedua terbesar setelah kelapa. Luas lahan panen padi sawah di Desa Cibuniasih dari tahun 2017-2019 tidak mengalami peningkatan yaitu 224 hektar luas panen dengan produksi 1523 ton (BPS Kabupaten Tasikmalaya, 2019).

Produksi padi sawah di Desa Cibuniasih masih tetap tidak mengalami peningkatan padahal keterlibatan antara penyuluh dan kelompok tani sangat membantu untuk meningkatkan kualitas petani. Oleh karena itu, peran penyuluh adalah mengarahkan dan membimbing kelompok tani yang diarahkan pada peningkatan fungsi dan penerapan pola usaha di bidang pertanian. Peran serta petani dan penyuluh melalui kerja sama untuk membangun sektor pertanian (Putra et al., 2018)

Kelompok tani di Desa Cibuniasih awalnya berjumlah 6 kelompok, lalu dibentuk 2 kelompok tani baru agar kegiatan kelompok tani berjalan lebih baik, tetapi langkah ini tidak berpengaruh terhadap hasil produksi padi sawah. Kondisi ini sama seperti yang dikemukakan oleh Nurjanah et al., (2016) bahwa banyak kelompok tani yang didirikan dan dikembangkan tetapi dalam kinerjanya masih dipertanyakan, kelompok tani didirikan hanya karena adanya tawaran berupa bantuan dari pemerintah untuk sarana produksi, modal dan teknologi. Dalam hal ini kurangnya bimbingan dari penyuluh pertanian menyebabkan pengelolaan input produksi 
petani menjadi kurang baik sehingga berpengaruh terhadap hasil produksi.

Kegiatan penyuluhan kepada petani oleh penyuluh pertanian yang bertugas di Desa Cibuniasih terlihat masih belum efektif. Sedangkan kegiatan penyuluhan merupakan media pembelajran yang penting untuk petani dalam meningkatkan keterampilan, pengetahuan, inovasi dan teknologi. Kegiatan penyuluhan bertujuan agar petani menjadi lebih baik dan mandiri dalam mengambil keputusan atau tindakan, sehingga mampu mempengaruhi hasil produksi padi sawah menjadi lebih baik. Maka dari itu peneliti tertarik untuk meneliti seberapa besar pengaruh peran penyuluh pertanian terhadap hasil produksi padi sawah di Desa Cibuniasih.

\section{METODE PENELITIAN}

Lokasi penelitian dipilih secara sengaja (purposive) yaitu Desa Cibuniasih Kecamatan Pancatengah Kabupaten Tasikmalaya. Alasan peneliti memilih lokasi ini karena terdapat kegiatan penyuluhan kepada petani padi sawah di Desa Cibuniasih yang sebagian besar penduduk merupakan petani padi sawah. Merujuk pada lokasi penelitian dengan karakteristik seperti keberadaan objek dan aktivitas yang sesuai, untuk mengetahui pengaruh peran penyuluh pertanian terhadap hasil produksi padi sawah.

Penelitian ini menggunakan metode kualitatif dan kuantitatif. Metode penelitian kualitatif yaitu metode penelitian yang digunakan untuk mencari kebenaran dari permasalahan yang sedang terjadi di lapangan dari pemahaman masyarakat, sikap sosial ataupun politik di daerah peneltian. Metode penelitian kuantitatif merupakan metode peneltian yang tersusun, digunakan untuk meneliti populasi atau sampel penelitian yang menghasilkan data berbentuk angka (Sugiyono, 2012).

$$
\text { Variabel-variabel }
$$
dioperasionalisasikan pada penelitian ini meliputi Peran penyuluh (X) dalam penelitian ini meliputi 4 dimensi yaitu sebagai pembimbing, organisator, teknisi dan konsultan bagi petani. Produksi padi sawah (Y) merupakan hasil panen dalam musim terakhir.

Teknik pengambilan sampel dilakukan dengan menggunakan rumus slovin. Rumus slovin digunakan untuk pengambilan jumlah sampel dari populasi petani padi sawah yang berjumlah 220 orang. 
Sumber data yang dibutuhkan terkait dengan penelitian yang akan dilakukan dibagi menjadi dua, yaitu:

a. Data primer, yaitu data yang diperoleh secara langsung dari hasil observasi lapangan dan wawancara dengan narasumber yaitu petani padi sawah yang ada di Desa Cibuniasih Kecamatan Pancatengah Kabupaten Tasikmalaya.

b. Data sekunder, yaitu data yang diperoleh untuk membantu menujang data primer yang diperoleh dari bahan pustaka, literatur, jurnal, buku, penelitian terdahulu, lembaga atau dinas terkait dengan penelitian ini.

Teknik pengumpulan data dalam penelitian ini disesuaikan dengan metode penelitian kualitatif dan kuantitatif. Teknik pengumpulan data dilakukan dengan wawancara dan observasi lapangan, menggunakan pertanyaan yang sudah dibuat terlebih dahulu (kuesioner). Kuesioner ini dibuat untuk mempermudah peneliti dalam pengumpulan data. Penyusunan kuesioner dalam penelitian ini menggunakan metode skoring skala likert, dimana setiap indikator dari variabel digunakan untuk membuat pertanyaan yang valid (Budiaji, 2013).
Penelitian ini menggunakan skala likert yang dilakukan tentang perilaku dan sifat manusia selalu dirancang sendiri oleh peneliti sesuai dengan kebutuhan dengan mengikuti pedoman (Budiaji, 2013). Interval skor dikategorikan sebagai berikut: $0 \%-19,9 \%=$ sangat kurang baik, 20\% - 39,9\% = kurang baik, $40 \%-59,9 \%=$ cukup baik, $60 \%-79,9 \%$ $=$ baik dan $80 \%-00 \%=$ sangat baik.

Uji asumsi klasik dilakukan untuk memastikan bahwa hasil penelitian ini valid dengan data yang digunakan secara teori atau tidak bias, konsisten dan penaksiran koefisien regresinya efisien. Penelitian menggunakan tiga uji asumsi klasik yaitu uji normalitas, multikolinearitas, dan heteroskedastisitas.

Analisis regresi linier berganda digunakan untuk mengukur hubungan peran penyuluh pertanian terhadap hasil produksi padi sawah. Kriteria pengukuran variabel independen, yaitu peran penyuluh pertanian sebagai pembimbing (X1), organisator (X2), teknisi (X3), dan konsulta (X4) terhadap variabel dependen yairu produksi (Y). Analisis regresi linier berganda untuk melihat hubungan secara linier antara variabel independen yaitu peran penyuluh $(\mathrm{X} 1, \mathrm{X} 2, \mathrm{X} 3, \mathrm{X} 4)$ terhadap variabel dependen yaitu hasil produksi (Y) dengan persamaan matematika: 
$\mathrm{Y}=\mathrm{a}+\mathrm{b} 1 \mathrm{X} 1+\mathrm{b} 2 \mathrm{X} 2+\mathrm{b} 3 \mathrm{X} 3+\mathrm{b} 4 \mathrm{X} 4+\mathrm{e}$

Dimana: $\mathrm{Y}=$ Produksi, $\mathrm{a}=$ Nilai konstanta, $\mathrm{b}=$ Koefisien Regresi, X1 = Pembimbing, $\mathrm{X} 2$ = Organisator, $\mathrm{X} 3=$ Teknisi, $\mathrm{X} 4=$ Konsultan, $\mathrm{e}=$ Batas Kesalahan. Kemudian dilakukan Uji F untuk menguji pengaruh variabel secara serempak, Uji t untuk menguji pengaruh masing-masing variabel, dan uji koefisien determinasi untuk mengetahui kekuatan pengaruh antara variabel $\mathrm{X}$ terhadap $\mathrm{Y}$.

\section{HASIL DAN PEMBAHASAN}

Berdasarkan uji asumsi klasik semua data hasil penelitian berdistribusi normal. Hasil uji normalitas data berdasarkan uji Kolmogorov-Smirnov Z diketahui bahwa nilai Asymp. Sig (2 tailed) diperoleh 0,147 lebih besar dari 0,05 yang berarti semua variabel dinyatakan berdistribusi normal. Hasil uji multikolinearitas menunjukan bahwa seluruh variabel independen tidak memiliki nilai tolerance lebih besar daripada 1 yang berarti tidak terdapat korelasi antar variabel yang nilainya lebih dari 95\%. Selanjutnya nilai Variance Inflation Factor (VIF) juga menunjukan bahwa tidak ada nilai yang kurang dari 1 dan lebih dari 10, jadi model regresi yang digunakan dalam penelitian ini tidak terdapat multikolineinearitas. Uji hetereoskedastisitas menggunakan uji Glejser untuk variabel independen Pembimbing $\left(\mathrm{X}_{1}\right)$ diperoleh 0.654, Organisator $\left(\mathrm{X}_{2}\right)=0.163$, Teknisi $\left(\mathrm{X}_{3}\right)=$ 0.194 dan Konsultan $\left(\mathrm{X}_{4}\right)=0.916$, nilai ABS_RES probabilitas signifikansinya diatas 0.05 atau 5\%. nilai tersebut menunnjukan bahwa tidak terdapat gejala heteroskedastisitas. Grafik scatterplots juga memperlihatkan tidak terdapat gejala heteroskedastisitas karena titiktitik menyebar di atas dan di bawah antara angka 0 .

Analisis regresi linier berganda digunakan untuk mengetahui seberapa besar peran penyuluh pertanian terhadap produksi padi sawah di Desa Cibuniasih Kecamatan Pancatengah Kabupaten Tasikmalaya. Terdapat empat variabel (X) yang menjadi fokus dalam penelitian ini yaitu peran penyuluh pertanian sebagai Pembimbing $\left(\mathrm{X}_{1}\right)$, Organisator $\left(\mathrm{X}_{2}\right)$, Teknisi $\left(\mathrm{X}_{3}\right)$, Konsultan $\left(\mathrm{X}_{4}\right)$ terhadap Variabel dependen (Y) yaitu produksi padi sawah sebagaimana tersaji pada Tabel 1.

Berdasarkan Tabel 1 hasil uji regresi linier berganda antara variabel Pembimbing $\left(\mathrm{X}_{1}\right)$, Organisator $\left(\mathrm{X}_{2}\right)$, Teknisi $\left(\mathrm{X}_{3}\right)$, Konsultan $\left(\mathrm{X}_{4}\right)$ terhadap produksi padi sawah $(\mathrm{Y})$ sebagai berikut: 
$\mathrm{Y}=0.662+0.045 \mathrm{X} 1+0.052 \mathrm{X} 2+$ $0.028 \times 3+0.085 \times 4+0,5$

a. Peran penyuluh sebagai pembimbing $\left(\mathrm{X}_{1}\right)$ memperoleh nilai koefisien 0.045 yang bernilai positif. Jadi ketika kinerja peran penyuluh pertanian sebagai pembimbing meningkat sebesar $1 \%$ dengan asumsi peran penyuluh sebagai organisator, teknisi dan konsultan tetap maka produksi padi sawah meningkat sebesar $0.045 \%$.

b. Peran penyuluh sebagai organisator $\left(\mathrm{X}_{2}\right)$ memperoleh nilai koefisien 0.052 yang bernilai positif. Jadi ketika kinerja peran penyuluh pertanian sebagai organisator meningkat sebesar $1 \%$ dengan asumsi peran penyuluh sebagai pembimbing, teknisi dan konsultan tetap maka produksi padi sawah meningkat sebesar $0.052 \%$. c. Peran penyuluh sebagai teknisi $\left(\mathrm{X}_{3}\right)$ memperoleh nilai koefisien 0.028 yang bernilai positif. Jadi ketika kinerja peran penyuluh pertanian sebagai teknisi meningkat sebesar 1\% dengan asumsi peran penyuluh sebagai pembimbing, organisator dan konsultan tetap maka produksi padi sawah meningkat sebesar $0.028 \%$.

d. Peran penyuluh sebagai konsultan $\left(\mathrm{X}_{4}\right)$ memperoleh nilai koefisien 0.085 yang bernilai positif. Jadi ketika kinerja peran penyuluh pertanian sebagai konsultan meningkat sebesar $1 \%$ dengan asumsi peran penyuluh sebagai pembimbing, organisator dan teknisi tetap maka produksi padi sawah meningkat sebesar $0.085 \%$.

Tabel 1. Hasil Uji Regresi Linier Berganda

\begin{tabular}{|c|c|c|c|c|c|c|}
\hline & \multirow{2}{*}{ Model } & \multicolumn{2}{|c|}{ Unstandardized Coefficients } & \multirow{2}{*}{$\begin{array}{l}\text { Standardized Coefficients } \\
\text { Beta }\end{array}$} & \multirow{2}{*}{$\mathrm{t}$} & \multirow{2}{*}{ Sig. } \\
\hline & & $\mathrm{B}$ & Std. Error & & & \\
\hline \multirow{5}{*}{1} & (Constant) & .622 & .258 & & 2.411 & .019 \\
\hline & Pembimbing $\left(\mathrm{X}_{1}\right)$ & .045 & .021 & .241 & 2.091 & .041 \\
\hline & Organisator $\left(\mathrm{X}_{2}\right)$ & .052 & .041 & .189 & 1.249 & .216 \\
\hline & Teknisi $\left(\mathrm{X}_{3}\right)$ & .028 & .044 & .101 & .635 & .528 \\
\hline & Konsultan $\left(\mathrm{X}_{4}\right)$ & .085 & .028 & .374 & 2.989 & .004 \\
\hline
\end{tabular}

Uji $F$ dilakukan untuk mengetahui apakah terdapat hubungan secara simultan antara variabel independen yaitu peran penyuluh pertanian sebagai pembimbing, organisator, teknisi dan konsultan terhadap variabel dependen yaitu peningkatan produksi padi sawah. 
Tabel 2. Hasil Uji F hitung

\begin{tabular}{|c|c|c|c|c|c|}
\hline Model & Sum of Squares & df & Mean Square & $\mathrm{F}$ & Sig. \\
\hline Regression & 30.441 & 4 & 7.610 & $31.409 * *$ & $.000^{\mathrm{b}}$ \\
\hline Residual & 15.265 & 63 & .242 & & \\
\hline Total & 45.706 & 67 & & & \\
\hline
\end{tabular}

Berdasarkan Tabel 2 diperoleh nilai signifikansi 0,000 lebih kecil dari 0,05 yang berarti penelitian ini layak karena terdapat hubungan antara variabel (X) yaitu peran penyuluh pertanian sebagai pembimbing, organisator, teknisi dan konsultan seacara simultan berpengaruh terhadap variabel (Y) produksi padi sawah. Hasil uji analisi koefisien determinasi diperoleh nilai R Square $\left(\mathrm{R}^{2}\right)$ 0.666 atau $66.6 \%$. Jadi variabel independen yaitu peran penyuluh pertanian memberikan pengaruh sebesar $66.6 \%$ terhadap produksi padi sawah di Desa Cibuniasih dan sisanya dipengaruhi oleh variabel lain selain peran penyuluh pertanian.

Uji t dilakukan untuk mengetahui apakah masing-masing variabel (X) peran penyuluh pertanian memiliki pengaruh terhadap variabel (Y) produksi padi sawah.

a. Variabel $\left(\mathrm{X}_{1}\right)$ peran penyuluh pertanian sebagai pembimbing memperoleh nilai signifikan $(0.041<$ 0.25) yang berarti peran penyuluh pertanian sebagai pembimbing berpengaruh signifikan terhadap produksi padi sawah di Desa Cibuniasih.

b. Variabel $\left(\mathrm{X}_{2}\right)$ peran penyuluh pertanian sebagai organisator memperoleh nilai signifikan $(0.216<$ 0.25) yang berarti peran penyuluh pertanian sebagai organisator berpengaruh signifikan terhadap produksi padi sawah di Desa Cibuniasih.

c. Variabel $\left(\mathrm{X}_{3}\right)$ peran penyuluh pertanian sebagai teknisi memperoleh nilai signifikan $(0.528>0.25)$ yang berarti peran penyuluh pertanian sebagai teknisi tidak berpengaruh signifikan terhadap hasil produksi padi sawah di Desa Cibuniasih.

Variabel $\left(\mathrm{X}_{4}\right)$ peran penyuluh pertanian sebagai konsultan memperoleh nilai signifikan $(0.004<0.25)$ yang berarti peran penyuluh pertanian sebagai konsultan berpengaruh signifikan terhadap produksi padi sawah di Desa Cibuniasih.

\section{Penyuluh Sebagai Pembimbing}

Penyuluh pertanian sebagai pembimbing merupakan guru bagi petani dalam Pendidikan non formal, penyuluh 
harus mempunyai gagas yang kuat serta demontrasi yang tepat untuk memberikan contoh kepada petani. Peran penyuluh sebagai pembimbing menurut penilaian dari petani memperoleh nilai persentase 49,46\%, artinya secara umum kinerja penyuluh pertanian sebagai pembimbing berada pada kategori cukup baik. Berdasarkan hasil uji $\mathrm{t}$ parsial peran penyuluh sebagai pembimbing memperoleh nilai signifikan $(0.041<0.25)$ yang berarti berpengaruh signifikan. Hasil penelitian ini sesuai dengan yang di kemukakan oleh Susrusa, (2017) Penyuluh pertanian sebagai pembimbing memiliki kinerja yang sangat baik karena penyuluh memiliki gagasan yang tinggi dan mampu memberikan bimbingan kepada petani melalui Pendidikan non formal untuk mengatasi hambatan serta bantuan permodalan.

Peran penyuluh pertanian sebagai pembimbing kinerja dalam pembuatan jadwal penyuluhan untuk petani dirasa sudah cukup baik untuk petani di Desa Cibuniasih dengan pertemuan 2-4 kali dalam satu bulan. Menurut petani jika kegiatan penyuluhan terlalu sering dilakukan akan menggangu aktivitas kegiatan bertani yang dilakukan oleh petani. Kegiatan penyuluhan juga selalu dihadiri penyuluh untuk menyampaikan gagasan dan pengetahuan tentang teknik budidaya padi sawah dengan metode yang mudah untuk dipahami petani sehingga pengetahuan petani semakin bertambah. Petani padi di Desa Cibuniasih juga sering terkendala dengan biaya untuk proses pengembangan usahatani padi sawah. Sehingga penyuluh pertanian juga memberikan informasi permodalan kepada petani dengan memberikan rekomendasi agar bisa mendapatkan bantuan dari dinas pertanian ataupun instansi terkait lainnya. Ini sesuai dengan yang dikemukaan oleh Wicaksono, (2020) Peran penyuluh pertanian sebagai pembimbing memiliki gagasan yang tinggi dan berperan membantu menyelesaikan masalah yang dihadapi petani. Membimbing petani mengenai cara budidaya yang baik, dan mampu untuk memberikan solusi dana yang dapat digunakan oleh petani untuk mengembangkan usahataninya.

Dalam kegiatan penyuluhan penyuluh pertanian tidak bisa menjangkau semua petani yang ada di Desa Cibuniasih karena adanya keterbatasan tenaga penyuluh pertanian. Permasalahan ini kemudian di selesaikan dengan pembentukan kelompokkelompok tani yang kemudian dikembangkan sehingga mampu berperan 
dalam mengembangkan masyarakatnya. Kinerja penyuluh dalam proses ini yang kemudian menjadikan peran penyuluh sebagai organisator yang dapat dilihat pada pembahasan selanjutnya.

\section{Penyuluh Sebagai Organisator}

Peran penyuluh sebagai organisator adalah membantu pembentukan kelompok tani, mengorgansir tugas dan kebutuhan petani sehingga petani bisa mengelola dan mengembangkan usahataninya. Jumlah skor yang diperoleh penyuluh pertanian sebagai organisator yaitu 708 dengan persentase 52,05\% berada pada kategori cukup baik. Kemudian berdasarkan hasil uji t parsial memperoleh nilai signifikan $(0.216<$ 0.25) yang artinya peran penyuluh sebagai organisator berpengaruh signifikan terhadap hasil produksi padi sawah di Desa Cibuniasih. Kinerja penyuluh pertanian sebagai organisator dalam mengarahkan pembentukan kelompok tani serta penyusunan program kerja untuk kegiatan kelompok, sehingga kelompok tani bisa menjadi sarana untuk mengembangkan masyarakatnya dari segi keterampilan ataupun perekonomian. Karena menurut Lini et al., (2018) Peran penyuluh sebagai organisator adalah menyediakan wadah bagi petani untuk mengembangkan usahataninya melalui kegiatan kelompok tani dan penentuan program kerja. Sehingga kegiatan usahatani bisa dilakukan secara bersamasama dengan cara pembagian tugas agar kegiatan kelompok tani bisa berjalan dengan baik. Meskipun dalam proses pemenuhunan kebutuhan petani belum maksimal dikarenakan menurut Pramono et al., (2017) bahwa penyuluh belum mengetahui cara untuk mendata kebutuhan petani yang sesuai dengan potensi wilayah dan kebutuhan teknologi petani.

Kegiatan penyuluhan untuk pemberdayaan kelompok tani juga belum dilakukan secara berkelanjutan, meskipun kelompok tani sudah dibentuk akan tetapi dalam kegiatanya belum berjalan dengan maksimal. Keadaan ini sesuai dengan penelitian yang dilakukan oleh Yuniarti et al., (2017) Peran penyuluh pertanian sebagai organisator berada pada kategori rendah terhadap kegiatan pemberdayaan kelompok tani.

\section{Penyuluh Sebagai Teknisi}

Peran penyuluh sebagai teknisi adalah membantu petani mengembangkan usahataninya dari segi teknis seperti pelatihan cara penanaman padi sawah yang baik dan penyuluh harus 
memiliki pengetahuan serta keterampilan teknis yang baik.

Skor total yang diperoleh peran penyuluh sebagai teknisi adalah 637 dengan persentase $46,83 \%$ berada pada kategori cukup baik. Sedangkan berdasarkan hasil uji $\mathrm{t}$ parsial memperoleh nilai signifikan $(0.528>0.25)$ yang artinya peran penyuluh sebagai teknisi belum berpengaruh signifikan terhadap produksi padi sawah di Desa Cibuniasih. Peran penyuluh sebagai teknisi belum terlaksana dengan baik karena menurut Putra et al., (2018) dan Suparman, (2017) penyuluh pertanian seharus nya memiliki keterampilan dan pengetahuan yang baik yang baik untuk menyampaikan materi dan demonstrasi kepada petani. Karena teknologi dan inovasi memerlukan arahan dan bimbingan dari petani agar bisa diterapkan dengan baik oleh petani.

Kegiatan pelatihan yang diberikan penyuluh pertanian kepada petani di Desa Cibuniasih masih kurang efektif karena intensitas pelatihan dan demonstrasi dalam kurun waktu 6 bulan hanya dilakukan 1 atau 2 kali. Oleh karena itu Penyuluh pertanian harus mampu meningkatkan kegiatan demonstrasi/ pelatihan agar petan mudah untuk memahaminya. Pengenalan teknologi baru juga belum sesuai dengan kebutuhan dan sumber daya yang tersedia di Desa Cibunisasih yang bertujuan agar petani bisa memaksimalkan penggunaan teknologinya. Oleh karena itu, menurut Susilo \& Wijanarako, (2016) penyuluh pertanian perlu meningkatkan pemahaman terhadap potensi, sifat-sifat dan keadaan sumber daya alam, iklim dan wilayah binaaan. Karena menurut Tanjung et al., (2020) Penyuluh merupakan bagian penting dalam proses penyuluhan pertanian untuk menyampaikan teknologi dan inovasi kepada pelaku utama dengan cara yang mudah dipahami oleh petani. Dan menurut Indraningsih et al., (2010) Penyuluhan seharusnya dilaksanakan dengan menyesuaikan kebutuhan petani dengan melalui pendekatan menggunakan metode yang disesuaikan dengan potensi sumber daya wilayah binaan.

\section{Penyuluh Sebagai Konsultan}

Total skor yang diperoleh peran penyuluh sebagai konsultan berjumlah 808 dengan persentase $47,52 \%$ berada pad kategori cukup baik. Kemudian berdasarkan hasil uji $t$ parsial memperoleh nilai signifikan $(0.004<0.25)$ yang berarti berpengaruh signifikan. Hasil penelitian ini sesuai dengan apa 
yang di kemukakan oleh Putra et al., (2018) peran penyuluh sebagai konsultan memberikan pengaruh yang baik karena penyuluh pertanian aktip dalam mengajak dan mengadakan diskusi dengan petani untuk memecahkan permasalahan yang dihadapi petani. Penyuluh juga berperan baik untuk mengubungkan petani dengan lembaga terkait untuk pemasaran ataupun bantuan.

Peran penyuluh sebagai konsultan adalah sebagai sarana konsultasi untuk petani membantu memecahkan permasalahan yang dihadapi oleh petani, tanpa harus menunggu tetapi juga aktif menanyakan secara langsung kepada petani. Kemajuan teknologi dan komunikasi memudahkan proses konsultasi antara petani dan penyuluh. Kegiatan konsultasi jadi lebih mudah sehingga membantu petani dalam pemecahan masalah seperti penentuan benih unggul, pecegahan dan penanggulangan hama, penentuan kadar pestisida dan pupuk untuk tanaman padi sawah. Meskipun tidak terlalu efektif karena seharusnya dilakukan secara langsung dengan pengawasan dan pembimbingan dari penyuluh kepada petani. Tetapi setidaknya menjadi solusi untuk petani dalam menyelesaikan permasalahan yang mereka hadapi secara cepat dalam keadaan mendesak dan serba terbatas. Selaras dengan penelitian Nasro et al., (2012) dan Rokhman et al., (2019) Peran penyuluh pertanian sangat berperan dalam kegiatan penyuluhan memberikan kontribusi yang baik dalam memahami dan memberikan solusi untuk menyelesaikan masalah yang dihadapi petani.

\section{KESIMPULAN DAN SARAN}

\section{Kesimpulan}

Penyuluh berkontribusi nyata dalam memotivasi dan memberi solusi untuk meningkatkan hasil produksi padi sebesar $66,6 \%$. Peran penyuluh pertanian sebagai pembimbing berpengaruh signifikan terhadap produksi padi sawah di Desa Cibuniasih, artinya jadwal penyuluhan 2-4 kali dalam 1 bulan dirasa sudah cukup untuk petani. Akan tetapi peran penyuluh sebagi organisator belum berpengaruh signifikan terhadap hasil produksi padi sawah, karena kegiatan penentuan program kerja kelompok tani dan kebutuhan petani belum terpenuhi. Bersamaan dengan peran penyuluh pertanian sebagai teknisi juga belum berpengaruh signifikan terhadap produksi padi sawah di Desa Cibuniasih karena program pelatihan kepada petani 1-2 kali 
dalam kurun waktu 6 bulan dirasa masih kurang efektif bagi petani.

\section{DAFTAR PUSTAKA}

Amanah, S. (2007). Makna Penyuluhan dan Transformasi Perilaku Manusia. Jurnal Penyuluhan, 3(1). https://doi.org/10.25015/penyuluha n.v3i1.2152

BPS Kabupaten Tasikmalaya. (2019). Kabupaten Tasikmlaya Dalam Angka 2019. https://doi.org/1102001.3206

BPS Pusat. (2019). Badan Pusat Statistik. Kajian Konsumsi Bahan Pokok.

Budiaji, W. (2013). Skala Pengukuran dan Jumlah Respon Skala Likert. Ilmu Pertanian Dan Perikanan, 2(2), 127-133.

Fatchiya, A., Amanah, S., \& Kusumastuti, Y. I. (2016). Penerapan Inovasi Teknologi Pertanian dan Hubungannya dengan Ketahanan Pangan Rumah Tangga Petani. 12(2).

Hikmahwidi, R. (2018). Determination Of Main Commodity Of Food Crop And Ruminant Livestock In Tasikmalaya Regency. 4(1), 98110.

Indraningsih, K. S., Sugihen, B. G., \& Tjitropranoto, P. (2010). Kinerja Penyuluh dari Perspektif Petani dan Eksitensi Penyuluh Swadaya Sebagai Pendamping Penyuluh Pertanian. 8(4), 303-321.

Inten, S. M., Elviana, D., \& Rosen, B. (2017). Peranan Penyuluh Pertanian Dalam Peningkatan Pendapatan Petani Komoditas Padi Di Kecamatan Tanjungselor Kabupaten Bulungan. Jurnal AGRIFOR, XVI(1), 103-108.

Ishaq, M., Rumiati, A. T., \& Permatasari, O. (2017). Analisis Faktor-Faktor yang Mempengaruhi Produksi Padi di Provinsi Jawa Timur Menggunakan Regresi Semiparametrik Spline. 6(1).

Lini, L., Hamzah, A., \& Abdullah, S. (2018). Peranan Penyuluh Pertanian Dalam Pengembangan Kelompok Tani di Kelurahan Benua Nirae Kecamatan Abeli Kota Kendari. 3(5), 128-132.

Nasro, Saleh, A., Asngari, pang s, \& Muljono, P. (2012). Persepsi Penyuluh Pertanian Lapang Tentang Peranya Dalam Penyuluh Pertanian Padi di Provinsi Banten. Jurnal Penyuluh, 8(1).

Nurjanah, S., Cepriadi, \& Kausar. (2016). Peran Penyuluh Pertanian Dalam Pengembangan Kelompoktani Di Desa Kemuning Muda Kecamatan Bungaraya Kabupaten Siak. 3(2).

Pramono, H., Fatchiya, A., \& Sadono, D. (2017). Kompetensi Penyuluh Tenaga Harian Lepas Tenaga Bantu Penyuluh Pertanian di Kabupaten Garut, Jawa Barat. 13(2).

Putra, S., Defidelwina, \& Febrinova, R. (2018). Peran Penyuluh Pertanian Dalam Pengembangan Kelompok Tani Padi di Desa Rambah Baru Kecamatan Rambah Samo Kabupaten Rokan Hulu. Revista Brasileira de Ergonomia, 9(2), 621-633.

https://doi.org/10.5151/cidi2017060

Rokhman, W. N., Sholeh, M. S., \& Sustiyana. (2019). Peran penyuluh Pertanian dalam Pengembangan Kelompok Tani Sumber Jaya Jinangkah di Desa Teja Timur. November, 167-177.

Sugiyono. (2012). Metode Penelitian Kuantitatif, Kualitatif dan $R \& D$ (Metode Penelitian dan Pengembangan). Alfabeta.

Sugiyono. (2013). Metode Penelitian Kuantitatif kualitatif dan $R \& D$ 
(19th ed.). CV. ALFABETA.

Sundari, A Yusra, A. H., \& Nurliza. (2015). Peran Penyuluh Pertanian Terhadap Peningkatan Produksi Usahatani Di Kabupaten Pontianak Sundari1),. Social Economic of Agriculture, 4(1), 26-31.

Sundari, R. S., Arshad, A., Sulistyowati, L., Noor, T.I., Setiawan, I. 2021. Enhancing Food Security throughout Aquaponics in Urban Farming Development. Journal Physics Conferences Series 1764(1):12209. 10.1088/17426596/1764/1/012209

Suparman. (2017). Peran penyuluh pertanian dalam peningkatan produksi padi sa wah di kecamatan tabalar kabupatenberau. Universitas Terbuka Jakarta.

Susilo, A., \& Wijanarako. (2016). Kompetensi Penyuluh Pertanian dalam Menumbuhkan Potensi Agribisnis di Perkotaan. In Peran MST dalam Mendukung Urban Lifestyle yang Berkualitas (pp. 223-242). Universitas Terbuka.

Susrusa, K. B. (2017). Peranan Penyuluh Pertanian Lapangan Dalam Pembuatan Pupuk Organik Padat. E-Jurnal Agribisnis Dan Agrowisata, 6(1).

Sutrisno. (2016). Kinerja penyuluh pertanian dalam memberdayakan petani the performance of agricultural extension agent in empowering farmers. XII(1), 69-
80.

Tanjung, H. B., \& Wahyuni, S. (2020).

The Role Of Agricultural Extentions In Salibu Technology In Tanah Datar District, West Sumatera Province. AGRISEP, 19(2), 229-240. https://doi.org/10.31186/jagrisep.19 .2.229-240

Umbara, D. setia, Sulistyowati, L., Noor, T. isan, \& Setiawan, I. (2019). Ideal Agricultural Agent as a Logical Solution and Investment. World Journal of Agricultural Research, $7(1)$, 25-28. https://doi.org/10.12691/wjar-7-1-5 Vintaro, J., Sugandi, yogi suparyogi, \& Adiwisastra, $\mathrm{J}$. (2019). Perkembangan Penyuluh Pertanian Dalam Menudukung Pertumbuhan Pertanian Di Indonesia. Responsive, 1(3), 90-96.

Wicaksono, I. A. (2020). Peran Penyuluh Pertanian Lapang ( PPL ) Dalam Pemberdayaan Petani Di Kelompok Tani Sri Widodo Desa Lubang Lor Kecamatan Butuh Kabupaten Purworejo. Riset Agribisnis \& Peternakan, 5(1), 61-69.

Yuniarti, L., Rita, M., \& Dukaju, N. N. (2017). Peranan Penyuluh Pertanian Dalam Pemberdayan Kelompok Tani Di Kelurahan Sambutan Kota Samarinda. 14(2), 1-12. 